\title{
Camelinapuriste siipikarjan ruokinnassa
}

\author{
Jarmo Valaja $^{1)}$, Eija Valkonen ${ }^{1)}$, Eija Venäläinen ${ }^{3)}$, Tuomo Tupasela ${ }^{2)}$ ja Jaakko Hiidenhovi ${ }^{2}$ \\ ${ }^{1)}$ MTT, Kotieläintuotannon tutkimus, 31600 Jokioinen, etunimi.sukunimi@mtt.fi \\ ${ }^{2)}$ MTT, Biotekniikka- ja elintarviketutkimus, 31600 Jokioinen, etunimi.sukunimi@mtt.fi \\ ${ }^{3)}$ HK Ruokatalo Oy, Kariniementie 2, 27510 Eura, etunimi.sukunimi@hk-ruokatalo.fi
}

\section{Tiivistelmä}

Camelina eli kitupellava tai ruistankio (Camelina sativa) on ristikukkaisten heimoon kuuluva vanha öljykasvi, jonka viljely Suomessa on viimevuosina yleistynyt huomattavasti. Camelinan siementen öljypitoisuus on noin 40-47 \% kuiva-aineesta. Camelinan rasvoista $90 \%$ on tyydyttymättömiä ja välttämättömien omega-3-rasvahappojen ja erityisesti linoleenihapon määrä on korkea. Öljynpuristusprosessista sivutuotteena saatavan camelinapuristeen aminohappokoostumus on siipikarjalle sopiva. Ristikukkaisten kasvien siemenet sisältävät kuitenkin haitta-aineita, jotka voivat rajoittaa niiden rehukäyttöä. Haitta-aineet voivat vaikuttaa rehun maittavuuteen ja ravintoaineiden sulavuuteen. Nykyinen rehulainsäädäntö kieltääkin camelinan ja sen prosessituotteiden käytön rehuissa. Camelinapuristeen rehukäyttömahdollisuuksia on tutkittu vähän.

Tässä koesarjassa tutkittiin camelinapuristeen käyttömahdollisuuksia munivien kanojen ja broilereiden rehuna. Tutkimuksissa selvitettiin mahdollisuuksia korvata rehun tärkein valkuaislähde soijarouhe camelinapuristeella. Lisäksi tutkittiin camelinapuristeen vaikutuksia kanamunien ja broilerilihan rasvahappokoostumukseen ja aistinvaraiseen laatuun.

Munivien kanojen kokeessa käytettiin 280 LSL-kanaa, jotka kokeen alkaessa olivat 21 viikon ikäisiä. Koe kesti koko tuotantokauden eli 52 viikkoa. Koekäsittelyjä oli viisi: kontrollirehu ilman camelinapuristetta, ja rehut joiden soijarouheesta 25, 50, 75 tai $100 \%$ oli korvattu camelinapuristeella. Jokaisessa rehuryhmässä oli seitsemän kahdeksan kanan ruokintakerrannetta.

Broilerikokeessa kasvatettiin 2800 Ross 508 broileria 38 päivän ikään. Sukupuolilajitellut untuvikot jaettiin 48 karsinaan, 60 lintua kuhunkin sukupuolet eri karsinoihin. Yhdeksän päivän ajan kaikki linnut ruokittiin samalla starttirehulla. Koerehuja tarjottiin kymmenen päivän iästä alkaen. Koerehut sisälsivät $0,5,10,15,20$, tai $25 \%$ camelinapuristetta. Kontrollivalkuaisrehuna oli soijarouhe. Kutakin rehua sai neljä kukko- ja neljä kanakarsinaa.

Soijarouheen korvaaminen camelinapuristeella ei vaikuttanut kanojen munintaprosenttiin, mutta se vähensi rehunkulutusta ja pienensi tuotettujen munien keskipainoa sekä kanojen elopainoa. Camelinapuristeen käyttö ei vaikuttanut kanojen kuolleisuuteen, eikä eläinlääkärin tekemässä patologisessa tutkimuksessa löytynyt muutoksia. Camelinapuristetta saaneiden ryhmien ulostenäytteen kuiva-aine oli pienempi kuin kontrollirehua saaneiden ryhmien. Tämä voi viitata ravintoaineiden huonompaan sulavuuteen.

Camelinapuristeen osuuden lisääntyessä rehussa broilereiden kasvu heikkeni, rehunkulutus pieneni ja rehunmuuntosuhde kasvoi. Kasvun heikkeni eniten ryhmissä, joiden rehussa camelinapuristetta oli 20 tai $25 \%$. Lisäksi camelinapuriste näytti heikentävän erityisesti kukkobroilerien kasvua, joiden kasvupotentiaali on kanoja suurempi. Camelinapuriste pienensi broilereiden kuolleisuutta, mutta heikensi pehkun laatua.

Sekä munan keltuaisen että broilereiden rintafileen rasvahappokoostumus muuttui ihmisravitsemuksen kannalta edullisempaan suuntaan, kun rehun soijarouhetta korvattiin camelinapuristeella. Pitkäketjuisten omega-3-rasvahappojen pitoisuus keltuaisessa kasvoi ja omega-6- ja omega-3rasvahappojen keskinäinen suhde pieneni. Camelinapuriste ei heikentänyt kanamunan tai broilereiden rintafileiden aistinvaraista laatua.

Tämän kokeen tulosten perusteella camelinapuristetta voidaan syöttää muniville kanoille jopa pelkkänä valkuaisrehuna ( $26 \%$ rehusta) ilman haitallisia vaikutuksia kanojen terveyteen, tuotantoon tai munien aistinvaraiseen laatuun. Broilereiden rehuissa camelinapuristeen käyttömäärää on syytä rajoittaa 10\%:iin. Camelinapuriste muuttaa sekä munien että broilerilihan rasvahappokoostumusta terveellisemmäksi.

\section{Avainsanat}

Kitupellava, kana, broileri, valkuaisrehu, lihan ja kananmunien laatu. 


\section{Johdanto}

Camelina eli kitupellava tai ruistankio (Camelina sativa) on ristikukkaisten heimoon kuuluva vanha öljykasvi, jonka viljely Suomessa on viimevuosina yleistynyt huomattavasti. Camelinan siementen öljypitoisuus on noin 40-47\% kuiva-aineesta. Ravitsemuksellisesti camelina on erittäin mielenkiintoinen kasvi, koska sen rasvoista $90 \%$ on tyydyttymättömiä ja välttämättömien omega-3rasvahappojen ja erityisesti linoleenihapon määrä on suuri.

Öljynpuristusprosessista sivutuotteena saatavan camelinapuristeen aminohappokoostumus on siipikarjalle sopiva. Sen valkuainen sisältää lysiiniä vähemmän, mutta rikkipitoisia aminohappoja, metioniinia ja kystiiniä, enemmän kuin toinen ristikukkainen viljelykasvi rypsi (Tuori ym. 2000, Ryhänen ym. 2007). Ristikukkaisten kasvien siemenet sisältävät kuitenkin haitta-aineita, mm. glukosinolaatteja. Haitta-aineet voivat heikentää rehun maittavuutta ja ravintoaineiden sulavuutta. Nykyinen EU:n rehulainsäädäntö kieltääkin camelinan ja sen prosessituotteiden käytön rehuissa.

Camelinapuristeen rehukäyttömahdollisuuksia on tutkittu vähän. Camelinaöljyn käyttö on lisännyt kananmunan keltuaisen tyydyttymättömien rasvahappojen ja erityisesti omega-3-rasvahappojen pitoisuutta (Rokka ym. 2002). Camelinapuriste nostaa myös broilereiden rintalihaksen omega-3- rasvahappoja, mutta samalla hidastaa kasvua ja heikentää rehuhyötysuhdetta (Ryhänen ym. 2007).

Tässä koesarjassa tutkittiin camelinapuristeen käyttömahdollisuuksia munivien kanojen ja broilereiden rehuna. Tutkimuksissa selvitettiin mahdollisuuksia korvata rehun tärkein valkuaislähde soijarouhe camelinapuristeella. Lisäksi tutkittiin camelinapuristeen vaikutuksia kanamunien ja broilerilihan rasvahappokoostumukseen ja aistinvaraiseen laatuun.

\section{Aineisto ja menetelmät}

Kanakokeessa oli 280 LSL-kanaa, jotka kokeen alkaessa olivat 21 viikon ikäisiä. Kanat sijoitettiin 16 viikon iässä yksilöhäkkeihin. Kahdeksan rinnakkaista häkkiä muodosti yhden koeyksikön. Jokaisessa ruokintaryhmässä oli seitsemän koeyksikköä. Koe kesti koko tuotantokauden eli 52 viikkoa.

Koekäsittelyjä oli viisi: kontrollirehu ilman camelinapuristetta, ja rehut joiden soijarouheesta 25 , 50, 75 tai $100 \%$ oli korvattu camelinapuristeella. Kontrollirehu sisälsi ohraa, vehnää, kauraa, soijarouhetta, rypsiöljyä sekä tarvittavia kivennäis- ja hivenaineita, vitamiineja ja aminohappoja. Koerehuissa soijarouhetta korvattiin camelinapuristeella, jota tuli rehuihin 7, 13, 20 tai 26\%. Koekausi oli jaettu kolmeen ruokintavaiheeseen, joissa rehujen valkuais- ja energiapitoisuus aleni ja kalsiumpitoisuus nousi ruokintasuositusten mukaisesti (Tuori ym. 2000). Rehut olivat rakeistettuja. Kanat saivat vapaasti sekä rehua että vettä.

Kanat punnittiin jokaisen ruokintavaiheen alussa ja lopussa. Munantuotos ja rehunkulutus mitattiin neljän viikon jaksoissa. Jaksoja oli 13 . Kokeen aikana otettiin kaksi kertaa munanäytteet rasvahappo- ja aistinvaraisiin analyyseihin. Kokeen lopussa kaksi kanaa jokaisesta koeyksiköstä lähetettiin patologisiin tutkimuksiin. Lisäksi kahden kanan maksa ja kilpirauhaset punnittiin kokeen lopussa.

Broilerikokeessa kasvatettiin 2800 Ross 508 broileria untuvikosta 38 päivän teurastusikään. Sukupuolilajitellut untuvikot jaettiin 48 karsinaan, 60 lintua kuhunkin sukupuolet eri karsinoihin. Karsinoiden pehkumateriaalina käytettiin turpeen ja sahanpurun seosta. Jokaista koerehua söi neljä kukkoja kanakarsinaa. Ensimmäisen yhdeksän päivän ajan kaikki linnut ruokittiin samalla vehnästä ja soijarouheesta koostetulla starttirehulla. Koerehuja tarjottiin kymmenen päivän iästä alkaen.

Kuusi koerehut sisälsivät 0, 5, 10, 15, 20, tai $25 \%$ camelinapuristetta. Kontrollivalkuaisrehuna oli soijarouhe. Koerehut sisälsivät soijarouheen ja camelinapuristeen lisäksi vehnää, rypsiöljyä sekä tarvittavia kivennäis- ja hivenaineita, vitamiineja ja aminohappoja. Koerehuja täydennettiin myös kokkidiostaatilla, betaiinilla ja ß-glukanaasi-ksylanaasientsyymiseoksella (Avizyme 1202). Kaikki rehut olivat rakeistettuja, starttirehu $3 \mathrm{~mm}$ ja kasvatusrehu $4 \mathrm{~mm}$ läpimittaan. Linnut saivat rehua ja vettä vapaasti.

Broilerit punnittiin karsinoittain kokeen alussa, starttirehukauden lopussa (9 pv), 21 päivän iässä sekä kokeen lopussa. Samalla mitattiin myös syödyn rehun määrää. Kokeen lopussa jokaisen karsinan kuivikepehkusta otettiin näyte, josta määritettiin kuiva-aine. Linnut teurastettiin kaupallisessa teurastamossa, jossa mitattiin lintujen teuraspaino. Ennen teurastusta jokaisesta karsinasta lopetettiin kaksi lintua MTT:1lä. Lintujen rintalihat ja sisälmysrasvan osuus määritettiin. Samalla otettiin rintalihanäytteet rasvahappo- ja aistivaraisiin analyyseihin.

Rehuseoksista määritettiin rehuanalyysi ja camelinapuristeesta aminohappopitoisuus. Liha- ja kanamunanäytteiden rasvahappokoostumus määritettiin Rokan ym. (2002) ja Ryhäsen ym. (2007) 
kuvaamilla menetelmillä. Aistivaraisten analyysien toteuttamismenetelmät on kuvattu Valkosen ym. (2007) artikkelissa. Tulosten tilastollinen analysointi tehtiin SAS-ohjelmistolla. Ryhmien väliset erot testattiin ortogonaalisilla kontrasteilla.

\section{Tulokset ja tulosten tarkastelu}

Ruokintakokeissa käytetty camelinapuriste sisälsi raakavalkuaista 350, raakarasva 201, ja raakakuitua $125 \mathrm{~g} / \mathrm{kg}$ kuiva-ainetta. Puristeen valkuaisessa oli lysiiniä 4,8, metioniinia 1,7 ja kystiiniä 2,0 g/100 g valkuaista. Camelinapuristeen koostumus oli samanlainen kuin aikaisemmassa tutkimuksessa (Ryhänen ym. 2007). Se sisältää valkuaista yhtä paljon kuin rypsipuriste. Valkuaisessa on vähemmän lysiiniä ja hiukan enemmän rikkipitoisia aminohappoja, metioniinia ja kystiiniä, kuin rypsin valkuaisessa (Tuori ym. 2000). Camelinan kuitu on lignifikoitunutta ja erittäin huonosti sulavaa (Peiretti ja Meineri 2007). Camelina sisältää glukosinolaatteja jopa kymmenkertaa enemmän kuin rypsi (Ryhänen ym. 2007).

Soijarouheen korvaaminen camelinapuristeella ei vaikuttanut kanojen munintaprosenttiin tai munantuotokseen, mutta se vähensi rehunkulutusta (lineaarinen vaikutus $\mathrm{p}<0,05$ ) ja pienensi tuotettujen munien keskipainoa (lineaarinen vaikutus $\mathrm{p}<0,001$ ja toisen asteen vaikutus $\mathrm{p}<0,05$ ) sekä kanojen elopainoa (lineaarinen vaikutus $\mathrm{p}<0,001$ ja toisen asteen vaikutus $\mathrm{p}<0,05$ ). Camelinapuristeella ei ole tehty pitkäaikaisia munantuotantokokeita, joten aikaisempia vertailukohteita ei ole olemassa. Rapsipuristeen runsas käyttö (30\% rehusta) on myös pienentänyt munanpainoa (Jeroch ym. 1995). Kanojen painon lasku johtui todennäköisesti niukemmasta rehun kulutuksesta. Camelinan glukosinolaatit saattoivat huonontaa rehujen maittavuutta.

Camelinapuristeen käyttö ei vaikuttanut kanojen kuolleisuuteen, eikä eläinlääkärin tekemässä patologisessa tutkimuksessa löytynyt muutoksia. Camelinapuriste kuitenkin suurensi kanojen kilpirauhasia (lineaarinen vaikutus $\mathrm{p}<0.01$ ) ja pienensi maksan painoa (lineaarinen vaikutus $\mathrm{p}<0,001$ ). Suurentuneet kilpirauhaset saattoivat johtua camelinan glukosinolaateista.

Camelinapuristetta saaneiden ryhmien ulostenäytteen kuiva-aine oli pienempi kuin kontrollirehua saaneiden ryhmien (lineaarinen vaikutus $\mathrm{p}<0,001$ ). Camelinapuristeen runsas kuitu huononsi luultavasti sulavuutta ja löystytti ulostetta.

Camelinapuristeen osuuden lisääntyessä rehussa broilereiden kasvu heikkeni, rehunkulutus pieneni ja rehunmuuntosuhde kasvoi (lineaarinen, toisen asteen ja kolmannen asteen vaikutukset $\mathrm{p}<0,001)$. Kasvun heikkeni erityisen jyrkästi, kun rehuissa oli camelinapuristetta 20 tai $25 \%$. Ryhäsen ym. (2007) tutkimustulokset olivat täysin samanlaisia. Broilereiden kasvu hidastui ja rehunmuuntosuhde heikkeni, kun rehut sisälsivät camelinapuristetta 5 tai 10\%. Roth-Mayerin ja Krichgessnerin (1987) tutkimuksen mukaan rapsirouhe käyttö broilereiden rehussa tulisi rajoittaa 15\%:iin. Camelinapuriste näytti heikentävän erityisesti kukkobroilerien kasvua, joiden kasvupotentiaali on kanoja suurempi.

Camelinapuriste vähensi broilereiden kuolleisuutta (lineaarinen vaikutus $p<0,01$ ). Aikaisemmassa tutkimuksessa camelinapuristeen käyttö ei vaikuttanut lintujen kuolleisuuteen (Ryhänen ym. 2007). Camelinapuriste pienensi pehkun kuiva-ainetta ja siten heikensi sen laatua (lineaarinen vaikutus $\mathrm{p}<0,001)$. Tämä johtui luultavasti löysästä ulosteesta, jonka aiheutti camelinan kuidun heikko sulavuus.

Sekä munan keltuaisen että broilereiden rintafileen rasvahappokoostumus muuttui ihmisravitsemuksen kannalta edullisempaan suuntaan, kun rehun soijarouhetta korvattiin camelinapuristeella. Pitkäketjuisten omega-3-rasvahappojen pitoisuus keltuaisessa kasvoi ja omega-6- ja omega-3rasvahappojen keskinäinen suhde pieneni. Samankaltaisia tuloksia on saatu myös Rokan ym. (2002) ja Ryhäsen ym. (2007) tutkimuksissa. Camelinalla on varsin selkeitä terveysvaikutuksia. Humaanitutkimuksissa camelinaöljy on alentanut seerumin kolesterolipitoisuutta (Karvonen ym. (2002).

Camelinapuriste ei vaikuttanut kanamunan tai broilereiden rintafileiden aistinvaraiseen laatuun. Rokan ym. (2002) tutkimuksessa camelinaöljy jopa paransi kananmunan aistinvaraista laatua. Ryhäsen ym. (2007) tutkimuksessa camelinapuriste ei myöskään vaikuttanut broilerilihan aistinvaraiseen laatuun.

\section{Johtopäätökset}

Kokeen tulosten perusteella camelinapuristetta voidaan syöttää muniville kanoille jopa pelkkänä valkuaisrehuna ( $26 \%$ rehusta) ilman haitallisia vaikutuksia kanojen terveyteen, tuotantoon tai munien 
aistinvaraiseen laatuun. Broilereiden rehuissa camelinapuristeen käyttömäärää on syytä rajoittaa 10\%:iin, koska broilereiden kehittymätön ruuansulatuskanava ei kykene sulattamaan camelinan kuituja.

Camelinapuriste muuttaa sekä munien että broilerilihan rasvahappokoostumusta terveellisemmäksi ja avaan uusia mahdollisuuksia funktionaalisten elintarvikkeiden tuotekehitykseen.

\section{Kiitokset}

Kiitokset Raisio Oyj:1le taloudellisesta tuesta ja hyvästä yhteistyöstä.

\section{Kirjallisuus}

Jeroch, H., Danicke, S. \& Zachmann, R. 1995. Zum Futterwert und zur Eignung von Rapsexpellern in der Legenhennenfutterung. Agribiol. Res. 48: 248-256.

Karvonen, H.M., Aro, A., Tapola, N.S., Salminen, I., Uusitupa, M.I.J. \& Sarkkinen, E.S. 2002. Effect of $\alpha$ linolenic acid-rich Camelina sativa oil on serum fatty acid composition and serum lipids in hypercholesterolemic subjects. Metabolism 51: 1253-1260.

Peiretti, P.G. \& Meineri, G. 2007. Fatty acids, chemical composition and organic matter digestibility of seeds and vegetative parts of false flax (Camelina sativa L.) after different lengths of growth. Anim. Feed Sci. Technol. 133: 341-350.

Rokka, T., Alen, K., Valaja, J. \& Ryhänen, E-L. 2002. Effect of a Camelina sativa enriched diet on the composition and sensory quality of hen eggs. Food Res. Int. 35:253-256.

Roth-Maier, D.A. \& Kirchgessner, M. 1987. Zum Einzatz von Rapsextraktionsschrot aus 00-Sorten in der Broilermast. Arch. Geflügelk. 51: 241-246.

Ryhänen, E-L., Perttilä, S., Tupasela, T., Valaja, J., Eriksson, C. \& Larkka, K. 2007. Effect of Camelina sativa expeller cake on performance and meat quality of broilers. J. Sci. Food Agric.

Tuori, M., Kaustell, K., Valaja, J., Aimonen, E., Saarisalo, E. \& Huhtanen, P. 2000. Rehutaulukot ja ruokintasuositukset. Märehtijät- siat- siipikarja - turkiseläimet - hevoset. 88 s. ISBN 951-45-9564-5. Yliopistopaino, Helsinki.

Valkonen, E., Venäläinen, E., Tupasela, T., Hiidenhovi, J. \& Valaja, J. 2007. Camelina sativa cake in poultry diets. XVII and XII Europian symposium on the quality of poultry meat and eggs. Prague 2.-5.9.2007. 
Taulukko 1. Camelinapuristeen vaikutus munivien kanojen tuotantotuloksiin.

\begin{tabular}{|c|c|c|c|c|c|c|c|c|c|}
\hline $\begin{array}{l}\text { Re- } \\
\text { hu }\end{array}$ & Cp, \% & $\mathbf{N}$ & $\begin{array}{c}\text { Munin- } \\
\text { ta-\% }\end{array}$ & $\begin{array}{l}\text { Munan } \\
\text { paino, g }\end{array}$ & $\begin{array}{l}\text { Munan- } \\
\text { tuotos, } \\
\text { g/kana/pv }\end{array}$ & $\begin{array}{c}\text { Rehun } \\
\text { kulutus, } \\
\text { g/kana/pv }\end{array}$ & $\begin{array}{c}\text { Rehu- } \\
\text { hyö- } \\
\text { tysuhde }\end{array}$ & $\begin{array}{l}\text { Kuollei- } \\
\text { suus, \% }\end{array}$ & $\begin{array}{c}\text { Ulosteen } \\
\text { kuiva- } \\
\text { aine, \% }\end{array}$ \\
\hline 1 & 0 & 7 & 90,0 & 63,7 & 57,2 & 117,0 & 2,06 & 7,1 & 31,3 \\
\hline 2 & 7 & 7 & 91,4 & 63,1 & 57,7 & 115,8 & 2,01 & 3,6 & 30,5 \\
\hline 3 & 13 & 7 & 91,4 & 63,5 & 58,0 & 117,1 & 2,03 & 1,8 & 29,3 \\
\hline 4 & 20 & 7 & 90,9 & 63,0 & 57,2 & 114,9 & 2,02 & 3,6 & 27,8 \\
\hline \multirow[t]{6}{*}{5} & 26 & 7 & 90,6 & 60,8 & 55,0 & 111,4 & 2,03 & 1,8 & 26,3 \\
\hline & & SEM & 6,438 & 1,676 & 4,123 & 5,0236 & 0,119 & 2,48 & 0,881 \\
\hline & $\begin{array}{l}\text { Ortogonaa- } \\
\text { liset kont- } \\
\text { rastit }^{1)}\end{array}$ & $\mathrm{C} 1$ & ns & * & ns & ns & ns & ns & $* *$ \\
\hline & & $\mathrm{C} 2$ & ns & $* * *$ & ns & $*$ & ns & ns & $* * *$ \\
\hline & & $\mathrm{C} 3$ & ns & $*$ & ns & ns & ns & ns & $\mathrm{ns}$ \\
\hline & & $\mathrm{C} 4$ & ns & ns & ns & ns & ns & ns & ns \\
\hline
\end{tabular}

1) C1=Kontrolli ( $\%$ Camelinap.) vs. muut ryhmät, C2=Camelinapuristeen lineaarinen vaikutus,

C3=Kamelinapuristeen toisen asteen vaikutus, C4=Kamelinapuristeen kolmannen asteen vaikutus.

$\mathrm{Cp}=$ camelinapuriste.

Taulukko 2. Camelinapuristeen vaikutus kananmunan keltuaisen rasvahappoihin (g/100 g rasvahappoja).

\begin{tabular}{|c|c|c|c|c|c|c|c|c|c|c|c|c|c|}
\hline $\begin{array}{l}\text { Re } \\
\text { hu }\end{array}$ & $\begin{array}{c}\text { Cp, } \\
\%\end{array}$ & $\mathbf{N}$ & 16:0 & 18:0 & 18:1 & $18: 2$ & 18:3 & $20: 4$ & $20: 5$ & 22:6 & n-3 & n-6 & $\begin{array}{c}\text { n-6:n-3- } \\
\text { suhde }\end{array}$ \\
\hline 1 & 0 & 4 & 23,6 & 9,15 & 45,3 & 12,8 & 0,72 & 2,04 & 0,00 & 1,41 & 2,42 & 15,2 & 6,30 \\
\hline 2 & 7 & 4 & 23,6 & 8,77 & 45,0 & 13,2 & 1,26 & 1,59 & 0,00 & 1,64 & 3,22 & 15,2 & 4,73 \\
\hline 3 & 13 & 4 & 23,1 & 9,21 & 43,7 & 13,6 & 2,13 & 1,36 & 0,06 & 1,89 & 4,47 & 15,4 & 3,45 \\
\hline 4 & 20 & 4 & 22,1 & 9,64 & 43,0 & 13,8 & 2,90 & 1,19 & 0,08 & 2,05 & 5,43 & 15,6 & 2,88 \\
\hline 5 & 26 & $\begin{array}{c}4 \\
\text { SEM }\end{array}$ & 21,9 & 9,26 & 41,5 & 14,6 & 3,74 & 1,10 & 0,08 & 2,21 & 6,46 & 16,4 & 2,53 \\
\hline \multirow{4}{*}{\multicolumn{2}{|c|}{$\begin{array}{l}\text { Ortogonaa- } \\
\text { liset kont- } \\
\text { rastit }^{1)}\end{array}$}} & $\mathrm{C} 1$ & $* * *$ & ns & $* * *$ & $* * *$ & $* * *$ & $* * *$ & $* * *$ & $* * *$ & $* * *$ & ns & $* * *$ \\
\hline & & $\mathrm{C} 2$ & $* * *$ & $*$ & $* * *$ & $* * *$ & $* * *$ & $* * *$ & $* * *$ & $* * *$ & $* * *$ & $* * *$ & $* * *$ \\
\hline & & C3 & $\mathrm{ns}$ & ns & * & ns & ns & $* * *$ & $* * *$ & ns & ns & * & $* * *$ \\
\hline & & C4 & $* *$ & $* *$ & ns & ns & ns & ns & $* * *$ & ns & ns & ns & ns \\
\hline
\end{tabular}

1) C1=Kontrolli ( $\%$ Camelinap.) vs. muut ryhmät, C2=Camelinapuristeen lineaarinen vaikutus,

C3=Kamelinapuristeen toisen asteen vaikutus, C4=Kamelinapuristeen kolmannen asteen vaikutus.

$\mathrm{Cp}=$ Camelinapuriste. 
Taulukko 3. Camelinapuristeen vaikutus broilereiden tuotantotuloksiin.

\begin{tabular}{|c|c|c|c|c|c|c|c|c|c|}
\hline Rehu & Ср, \% & Sukup. & $\mathbf{N}$ & $\begin{array}{c}\text { Loppu- } \\
\text { paino, g } \\
\text { (ikä } 37 \\
\text { pv) }\end{array}$ & $\begin{array}{l}\text { Kasvu, g } \\
10-37 \text { pv }\end{array}$ & $\begin{array}{c}\text { Rehun } \\
\text { kulutus } \\
\text { g/lintu/pv } \\
\text { 10-37 pv }\end{array}$ & $\begin{array}{c}\text { RHS } \\
\text { 10-37 pv }\end{array}$ & $\begin{array}{c}\text { Pehkun } \\
\text { kuiva- } \\
\text { aine, \% } \\
\text { (37 pv) }\end{array}$ & $\begin{array}{l}\text { Kuollei- } \\
\text { suus, \% } \\
10-37 \text { pv }\end{array}$ \\
\hline 1 & 0 & Kukko & 4 & 2522 & 2278 & 148 & 1.82 & 39 & 4,0 \\
\hline 2 & 5 & Kukko & 4 & 2427 & 2181 & 147 & 1.90 & 38 & 4,0 \\
\hline 3 & 10 & Kukko & 4 & 2422 & 2177 & 149 & 1.92 & 38 & 2,8 \\
\hline 4 & 15 & Kukko & 4 & 2390 & 2145 & 149 & 1.95 & 39 & 3,2 \\
\hline 5 & 20 & Kukko & 4 & 2132 & 1892 & 150 & 2.22 & 36 & 1,6 \\
\hline 6 & 25 & Kukko & 4 & 1677 & 1439 & 136 & 2.63 & 36 & 1,6 \\
\hline 1 & 0 & Kana & 4 & 2088 & 1860 & 131 & 1.97 & 41 & 2,0 \\
\hline 2 & 5 & Kana & 4 & 2077 & 1848 & 132 & 2.00 & 37 & 1,6 \\
\hline 3 & 10 & Kana & 4 & 2065 & 1834 & 133 & 2.04 & 37 & 0,8 \\
\hline 4 & 15 & Kana & 4 & 2022 & 1792 & 133 & 2.08 & 36 & 0,0 \\
\hline 5 & 20 & Kana & 4 & 1905 & 1676 & 132 & 2.21 & 38 & 0,8 \\
\hline \multirow[t]{13}{*}{6} & 25 & Kana & 4 & 1614 & 1379 & 128 & 2.58 & 37 & 0,0 \\
\hline & & & SEM & 35,4 & 22,7 & 1,5 & 0,027 & 1,5 & 0,82 \\
\hline & $\begin{array}{r}\text { Ortogor } \\
\text { tr }\end{array}$ & $\begin{array}{l}\text { et kon- } \\
\text { 1) }\end{array}$ & C1 & $* * *$ & $* * *$ & ns & $* * *$ & $*$ & $*$ \\
\hline & & & C2 & $* * *$ & $* * *$ & $* * *$ & $* * *$ & ns & $* *$ \\
\hline & & & C3 & $* * *$ & $* * *$ & $* * *$ & $* * *$ & $\mathrm{~ns}$ & ns \\
\hline & & & C4 & $* * *$ & $* * *$ & $* *$ & $* * *$ & ns & ns \\
\hline & & & C5 & ns & ns & ns & ns & ns & ns \\
\hline & & & C6 & $* * *$ & $* * *$ & $* * *$ & $* * *$ & ns & $* * *$ \\
\hline & & & C7 & $* * *$ & $* * *$ & ns & $*$ & ns & ns \\
\hline & & & C8 & $* * *$ & $* * *$ & $*$ & $* * *$ & ns & ns \\
\hline & & & C9 & $* *$ & $* *$ & ns & ns & ns & ns \\
\hline & & & C10 & $*$ & $*$ & ns & ns & ns & ns \\
\hline & & & C11 & ns & ns & ns & ns & ns & ns \\
\hline
\end{tabular}

1) C1=Kontrolli (0\% Camelinap.) vs. muut ryhmät, C2=Camelinapuristeen lineaarinen vaikutus,

$\mathbf{C 3}=$ Kamelinapuristeen toisen asteen vaikutus, $\mathbf{C 4}=$ Kamelinapuristeen kolmannen asteen vaikutus,

C5=Kamelinapuristeen neljännen asteen vaikutus, C6=Sukupuoli, C7=yhdysvaikutus C6*C1,

C8=yhdysvaikutus $\mathrm{C} 6 * \mathrm{C} 2, \mathbf{C 9}=$ yhdysvaikutus $\mathrm{C} 6 * \mathrm{C} 3, \mathbf{C 1 0}=$ yhdysvaikutus $\mathrm{C} 6{ }^{*} \mathrm{C} 4, \mathbf{C 1 1}=$ yhdysvaikutus $\mathrm{C} 6{ }^{*} \mathrm{C} 5$.

$\mathrm{Cp}=$ camelinapuriste.

Taulukko 4. Kamelinapuristeen vaikutus broilerin rintalihaksen rasvahappoihin (g/100 g rasvahappoja)

\begin{tabular}{|c|c|c|c|c|c|c|c|c|c|c|c|c|c|}
\hline $\mathbf{R}$ & $\begin{array}{l}\text { Cp } \\
\%\end{array}$ & $\mathbf{N}$ & $16: 0$ & 18:0 & $\begin{array}{c}\text { 18: } \\
1\end{array}$ & 18:2 & $18: 3$ & $20: 4$ & 20:5 & 22:6 & n-3 & n-6 & $\begin{array}{c}\text { n-6:n- } \\
\text { 3- } \\
\text { suhde }\end{array}$ \\
\hline 1 & 0 & 4 & 22,4 & 8,10 & 33,9 & 16,0 & 1,75 & 2,81 & 0,43 & 0,57 & 4,67 & 20,3 & 4,45 \\
\hline 2 & 5 & 4 & 21,9 & 8,39 & 30,7 & 17,0 & 3,47 & 2,87 & 0,75 & 1,11 & 8,03 & 21,6 & 2,71 \\
\hline 3 & 10 & 4 & 20,4 & 8,62 & 29,9 & 17,0 & 5,38 & 2,59 & 0,95 & 0,93 & 10,0 & 21,3 & 2,22 \\
\hline 4 & 15 & 4 & 20,2 & 8,86 & 28,3 & 17,5 & 5,31 & 2,95 & 0,97 & 1,33 & 10,7 & 22,6 & 2,12 \\
\hline 5 & 20 & 4 & 19,9 & 9,04 & 27,7 & 16,0 & 6,47 & 3,02 & 1,44 & 1,43 & 13,0 & 21,0 & 1,62 \\
\hline \multirow[t]{7}{*}{6} & 25 & 4 & 20,2 & 9,54 & $\begin{array}{l}23,7 \\
1,20\end{array}$ & 18,0 & 6,82 & 3,37 & 1,51 & 2,35 & 15,1 & 23,7 & 1,57 \\
\hline & $\begin{array}{l}\text { Ort } \\
\text { set }\end{array}$ & $\begin{array}{l}\text { SEM } \\
\text { laali- } \\
\text { tras- }\end{array}$ & 0,485 & 0,523 & 1 & 0,498 & 0,345 & 0,344 & 0,137 & 0,167 & 0,703 & 0,752 & 0,174 \\
\hline & & $\mathrm{C} 1$ & $* *$ & ns & $* * *$ & o & $* * *$ & ns & *** & $* * *$ & $* * *$ & $*$ & $* * *$ \\
\hline & & $\mathrm{C} 2$ & $* *$ & * & $* * *$ & o & $* * *$ & ns & $* * *$ & $* * *$ & $* * *$ & * & $* * *$ \\
\hline & & $\mathrm{C} 3$ & o & ns & ns & ns & $* *$ & $\mathrm{~ns}$ & ns & o & ns & $\mathrm{ns}$ & $* * *$ \\
\hline & & $\mathrm{C} 4$ & ns & ns & $\mathrm{ns}$ & $*$ & $\mathrm{~ns}$ & $\mathrm{~ns}$ & $\mathrm{~ns}$ & $*$ & $\mathrm{~ns}$ & $\mathrm{~ns}$ & $*$ \\
\hline & & $\mathrm{C} 5$ & ns & $\mathrm{ns}$ & ns & ns & ns & ns & ns & ns & $\mathrm{ns}$ & ns & o \\
\hline
\end{tabular}

1) C1=Kontrolli ( $0 \%$ Camelinap.) vs. muut ryhmät, C2=Camelinapuristeen lineaarinen vaikutus,

C3=Kamelinapuristeen toisen asteen vaikutus, C4=Kamelinapuristeen kolmannen asteen vaikutus,

C5=Kamelinapuristeen neljännen asteen vaikutus. $\mathrm{Cp}=$ kamelinapuriste; 